\title{
Brucella abortus causes an accelerated repopulation of the spleen and liver of mice by macrophages after their liposome-mediated depletion
}

\author{
ANTOINETTE M. J. BUITING, ZEGERINE DE ROVER and NICO VAN ROOIJEN \\ Department of Cell Biology and Immunology, Faculty of Medicine, Vrije Universiteit, van der Boechorststraat 7, 1081 \\ BT Amsterdam, The Netherlands
}

\begin{abstract}
Summary. Different macrophage subsets are present in the spleen, i.e., marginal zone macrophages (MZM), marginal metallophilic macrophages (MMM) and red pulp macrophages (RPM) and all are depleted by a single treatment with liposome-encapsulated clodronate. These macrophages can be distinguished by differences in localisation patterns, membrane antigens and repopulation kinetics after depletion. In experiments on the involvement of splenic macrophages in the humoral immune response, there was an acceleration of the repopulation kinetics of all macrophage subsets in the spleen after intravenous injection of an autoclaved suspension of Brucella abortus 544 (BA 544 antigen). The time required to obtain $100 \%$ repopulation in macrophage-depleted control mice was 2 weeks for RPM, 6 weeks for MMM and > 2 months for MZM. However, after BA 544 injection, $100 \%$ repopulation was obtained within 4 days in the case of RPM and within 2 weeks in the case of MMM. Acid phosphatase activity, indicating the presence of MZM, had returned to normal levels within 2 months. Acceleration of repopulation was observed only after intravenous administration of antigen preparations from Brucella strains (except strain BA 19). Although BA 544 antigen stimulated the proliferation of precursors of all of the macrophage subsets in the spleen and liver, it also affected mature members of the mononuclear phagocyte system such as MZM and dendritic cells in the spleen.
\end{abstract}

\section{Introduction}

Different macrophage subsets are present in the spleen, i.e., marginal zone macrophages (MZM), marginal metallophilic macrophages (MMM) and red pulp macrophages (RPM). These macrophages can be distinguished by differences in localisation, membrane antigens and repopulation kinetics after depletion by the liposome-mediated macrophage "suicide" approach., In this technique the macrophages phagocytose clodronate-containing liposomes and, after fusion with the lysosomes, the clodronate is released into the cell. The intracellular clodronate damages the cell and causes its elimination. Thus, all the different macrophage subpopulations in spleen (RPM, MMM and MZM) and liver (Kupffer cells) are depleted after intravenous injection of clodronateliposomes. After depletion, differences in repopulation kinetics of the different macrophage subpopulations have been demonstrated. The time required to obtain

Received 30 March 1994; revised version accepted 15 Aug. 1994.
$100 \%$ repopulation was about 2 weeks for RPM, 6 weeks for MMM and > 2 months for MZM. The repopulation kinetics of the Kupffer cells were similar to those of RPM. ${ }^{3}$

It has been shown in several studies that various cell populations in the spleen are affected by Brucella abortus antigen (BA) preparations. BA is a thymusindependent particulate antigen (type 1$).^{4-6}$ Consequently, B cells can be activated by BA in all mouse strains. Proliferation of bovine lymphocytes can be induced by several BA proteins only after previous vaccination with $\mathrm{BA} .{ }^{7} \mathrm{~A} B$. abortus infection causes hepatosplenomegaly and an influx of monocytes has been shown by measurement of lysozyme mRNA in northern blots. ${ }^{8}$ B. abortus strain 19 has been used as a non-specific stimulant to induce an immune response against TNP-Ficoll. ${ }^{9}$ This strain has also been proposed as a promising adjuvant in vaccines because its lipopolysaccharide (LPS) does not induce toxic shock, unlike LPS from Escherichia coli. ${ }^{10}$

In this study, the repopulation kinetics of all splenic macrophage subsets and Kupffer cells after intra- 
venous administration of autoclaved suspensions of $B$. abortus and related strains was examined. The effect of Brucella strains on the different macrophage subsets in spleens and livers of control (undepleted) mice was also examined.

\section{Materials and methods}

\section{Materials}

Antigens used for this study were prepared from $B$. abortus type strains 544 and 19-BA 544, BA 19; thymus-independent type 1 (TI-1)-B. melitensis $16 \mathrm{M}$ (TI-1), B. ovis reo 198 (TI-1), Lactobacillus acidophilus NCK89 (thymus-dependent, TD; Central Veterinary Institute, Lelystad, The Netherlands) and E. coli EB1 (TI-1; a serum-resistant isolate from a urinary tract infection; kindly provided by Dr F. Namavar, Department of Medical Microbiology, Faculty of Medicine, Vrije Universiteit, Amsterdam, The Netherlands). Bacterial suspensions were heated at $120^{\circ} \mathrm{C}$ for $20 \mathrm{~min}$ and were standardised on the basis of the dry weight of bacteria. Other antigens were sheep red blood cells (SRBC; TD) and LPS (TI). LPS (L-8274 from E. coli serotype O26: $\mathrm{B} 6$ ), ovalbumin (OVA: grade $\mathrm{V}$; A 5503), cholesterol, mannan (M-7504) and diaminobenzidine-tetrahydrochloride (DAB) were all obtained from Sigma.

Monoclonal antibodies (MAbs) used for the detection of macrophages by immunocytochemical staining were: MOMA-1 for detecting the MMM, ${ }^{11}$ ERTR-9 for detecting the MZM, ${ }^{12,13}$ MOMA-2 for recognising monocytes and macrophages, ${ }^{14} \mathrm{~F} 4-80$ for recognising all macrophages except the macrophages in the T- and B-cell areas of the lymphoid organs, ${ }^{15}$ and NLDC- $145^{16}$ and $6 \mathrm{D} 2^{17}$ for detecting dendritic cells (DC). Kupffer cells were detected by different MAbs, i.e., MOMA-2, F4-80 and MOMA-1. All MAbs were kindly provided by Dr G. Kraal (Department of Cell Biology and Immunology, Faculty of Medicine, Vrije Universiteit). The conjugate used was peroxidase-conjugated rabbit anti-rat IgG ( $\alpha$ Ra/HRP; Dako, Copenhagen, Denmark).

\section{Preparation of liposomes}

Clodronate-liposomes were prepared as described previously. ${ }^{1}$ Briefly, $86 \mathrm{mg}$ of phosphatidylcholine (LIPOID $\mathrm{E}$ PC, a kind gift of LIPOID $\mathrm{KC}$, Ludwigshafen, Germany) and $8 \mathrm{mg}$ of cholesterol were dissolved in $10 \mathrm{ml}$ of chloroform in a $500-\mathrm{ml}$ roundbottomed flask. After low-vacuum evaporation of the chloroform at $37^{\circ} \mathrm{C}$, a thin film formed on the interior wall of the flask. Then, $10 \mathrm{ml}$ of PBS containing $2.5 \mathrm{~g}$ of clodronate (dichloromethylene-bisphosphonate, a kind gift of Boehringer Mannheim GmbH, Germany) was added and the film was dispersed by gentle rotation at room temperature. The fluid was kept at room temperature for $2 \mathrm{~h}$, sonicated for $3 \mathrm{~min}$ and then kept at room temperature for another $2 \mathrm{~h}$. The liposomes were centrifuged for $15 \mathrm{~min}$ at $10000 \mathrm{~g}$ and washed twice by centrifugation with PBS at $24000 \mathrm{~g}$ for $30 \mathrm{~min}$. The pellet was resuspended in $4 \mathrm{ml}$ of PBS.

LPS-liposomes were prepared as described previously. ${ }^{18}$ Phosphatidylcholine $86 \mathrm{mg}$ and cholesterol $8 \mathrm{mg}$ were dissolved in $10 \mathrm{ml}$ of chloroform in a $500-\mathrm{ml}$ round-bottomed flask and, after evaporation, a thin film was formed. Then, $4 \mathrm{ml}$ of LPS solution, $0.5 \mathrm{mg} / \mathrm{ml}$ in PBS, was added directly to the flask to prepare the suspension of LPS-liposomes. The liposomes were washed twice with PBS by centrifugation at $24000 \mathrm{~g}$ for $30 \mathrm{~min}$ to remove free LPS. The pellet was resuspended in $4 \mathrm{ml}$ of PBS.

\section{Experimental design}

Female mice (C57BI/6 $\times$ DBA/2)F1 (Harlan, Zeist, The Netherlands), 6-8 weeks old, were given $0.2 \mathrm{ml}$ of clodronate liposomes by intravenous injection to deplete the macrophages. After 48 h, BA 544, BA19, $B$. melitensis 16M, B. ovis reo 198, E. coli EB1, $L$. acidophilus NCK89, LPS (from $E$. coli), mannan, human TNF- $\alpha$, LPS-liposomes or SRBC were injected intravenously in various doses. In the case of BA 544, the effect of injection was also studied in control mice. Thus, four groups of mice were included: 1A, control mice (no treatment); 1B, control (non-depleted) mice given BA 544 or other antigen as stimulation; $2 \mathrm{~A}$, depleted mice; $2 \mathrm{~B}$, depleted mice given BA 544 or other antigen as stimulation. The mice were killed 2,4 , $8,16,32$ and 64 days after injection of antigen (four mice/group/time interval).

\section{Dendritic cell isolation}

Adherent spleen dendritic cells were prepared as described previously but with slight modification. ${ }^{19}$ Briefly, collagenase $(1 \mathrm{mg} / \mathrm{ml}$ in RPMI 1640 containing $0.01 \mathrm{M}$ Hepes) and DNAase $(260 \mathrm{U} / \mathrm{ml}$ in RPMI+Hepes)-digested spleen tissue was treated with $\mathrm{NH}_{4} \mathrm{Cl}$ to shock the erythrocytes and then cytospin preparations were made. The rest of the cells were cultured in RPMI + Hepes supplemented with $2 \mathrm{~mm}$ glutamine, penicillin $10 \mathrm{U} / \mathrm{ml}$, streptomycin $100 \mu \mathrm{g} / \mathrm{ml}$, fetal calf serum (FCS; Greiner) $10 \% \mathrm{v} / \mathrm{v}$ and $5 \times 10^{-5} \mathrm{M} \quad \beta$-mercaptoethanol ( $\beta$-ME) (supplemented RPMI) in a plastic culture flask for $1.5 \mathrm{~h}$ at $37^{\circ} \mathrm{C}$. Cytospin preparations were made of the cells from the supernate. The attached cells were cultured for $18 \mathrm{~h}$. The dendritic cells were now in the supernate and the macrophages were still attached to the flask. Cytospin preparations were stained to identify the cells present.

\section{Isolation of ovalbumin-stimulated $T$ cells $\left(T_{O V A}\right)$}

Mice were given $50 \mu \mathrm{g}$ of OVA emulsified with Freund's complete adjuvant (Difco) by subcutaneous injection in all four ankles 10 days before $\mathrm{T}$ cell 
isolation. Cell suspensions from the spleen and the lymph nodes, after $\mathrm{NH}_{4} \mathrm{Cl}$ treatment, were cultured in supplemented RPMI in plastic tissue culture flasks for $2 \mathrm{~h}$. Non-adherent cells were incubated with MAbs 187/1 (anti-kappa) and M5/114 (anti-MHC class II; ATCC TIB 120) (kindly provided by Dr G. Kraal, Department of Cell Biology and Immunology, Faculty of Medicine, Vrije Universiteit) followed by incubation with sheep anti-rat IgG ( $\mathrm{Fc}$ )-coated dynabeads ${ }^{\text {mo }}$ (M-450, DYNAL A.S. N-0212 Oslo, Norway) to obtain a highly purified ( $>98 \%$ ) T-cell population.

\section{OVA-induced T-cell proliferation assay}

$\mathrm{T}_{\text {ovA }}$-lymphocytes $\left(4 \times 10^{5}\right.$ cells $/$ well $)$ were cultured together with dendritic cells (DC; $2 \times 10^{4}$ cells/well) in flat-bottomed 96-well plates for 3 days in supplemented RPMI. Three different groups of DC were tested, i.e., DC obtained from mice treated with clodronate-liposomes and then with BA 544 (group 2B) after 8 days $\left(\mathrm{DC}^{*}\right)$, DC from naive mice, and a combination of these two (ratio 1:1). During cultivation, the DC were stimulated with OVA $(100 \mu \mathrm{g} / \mathrm{ml}$ of medium) and $16 \mathrm{~h}$ before cell harvesting, ${ }^{3} \mathrm{H}$-thymidine $(1 \mu \mathrm{Ci} /$ well; Amersham) was added. Inhibition of Ia-dependent T-cell proliferation was performed by addition of anti-Ia antibody (M5/114; $25 \mu \mathrm{l}$ of cell culture supernate/well). Incorporation of the isotope was measured by liquid scintillation counting.

\section{In-situ characterisation of macrophages and dendritic cells}

The spleens and livers of the mice were removed, immediately frozen in liquid nitrogen, stored at $-20^{\circ} \mathrm{C}$ and cut into sections of $8 \mu \mathrm{m}$ thickness. The bone marrows of the mice were collected and cytospin preparations were made. The slides and cytospin preparations were dried overnight with silica gel and then fixed in acetone (analytical grade) for $10 \mathrm{~min}$ at room temperature.

Three different staining procedures were used: (a) a normal immunocytochemical stain; (b) an acid phosphatase stain; and (c) a combination of the two.

For (a), the slides or cytospin preparations were incubated with MAbs MOMA-1, ERTR-9, MOMA2, F4-80, NLDC-145 or $6 \mathrm{D} 2$ for $1 \mathrm{~h}$ at room temperature. They were then rinsed three times with PBS $(0.01 \mathrm{M}, \mathrm{pH} 7.4)$ and incubated with a 1 in 100 dilution of $\mathrm{R} \alpha \mathrm{Ra} / \mathrm{HRP}$ for $1 \mathrm{~h}$ at room temperature. The slides were rinsed three times with PBS and the peroxidase was demonstrated after incubation for $20 \mathrm{~min}$ with DAB, $0.5 \mathrm{mg} / \mathrm{ml}$ in $0.05 \mathrm{M}$ Tris- $\mathrm{HCl}, \mathrm{pH} 7.6$, containing $\mathrm{H}_{2} \mathrm{O}_{2} 0.03 \% \mathrm{v} / \mathrm{v}$. The slides were rinsed twice with PBS, with distilled water and finally with $\mathrm{NaCl}$ $0.9 \% \mathrm{w} / \mathrm{v}$. The slides were dipped in $\mathrm{CuSO}_{4} 0.5 \% \mathrm{w} / \mathrm{v}$ in $\mathrm{NaCl} 0.9 \% \mathrm{w} / \mathrm{v}$ for $10 \mathrm{~min}$ to intensify the staining, followed by a short dip in distilled water. Counterstaining was performed with haematoxylin.
For (b), the slides or cytospin preparations were incubated with a solution of naphthol-AS-MX-phosphate as substrate for acid phosphatase ${ }^{20}$ and hexazotised pararosaniline as diazonium salt ${ }^{21}$ for $15-60 \mathrm{~min}$ at $37^{\circ} \mathrm{C}$.

For (c), in the double-staining procedure, slides or cytospin preparations were incubated with $\mathrm{MAb}$ NLDC-145 for $1 \mathrm{~h}$ at room temperature. They were rinsed three times with PBS $(0.01 \mathrm{M}, \mathrm{pH} 7.4)$ and incubated with a 1 in 100 dilution of $\mathrm{R} \alpha \mathrm{Ra} / \mathrm{HRP}$ for $1 \mathrm{~h}$ at room temperature. They were then rinsed three times with PBS and the peroxidase was demonstrated with $\mathrm{DAB} 0.5 \mathrm{mg} / \mathrm{ml}$ in $0.05 \mathrm{M}$ Tris- $\mathrm{HCl}$, $\mathrm{pH} 7.6$, containing $\mathrm{H}_{2} \mathrm{O}_{2} 0.03 \% \mathrm{v} / \mathrm{v}$ incubated for $20 \mathrm{~min}$. Then, the slides were incubated in a solution of naphthol-AS-MX-phosphate as substrate ${ }^{20}$ and hexazotised pararosaline as diazonium salt ${ }^{21}$ for $15-60 \mathrm{~min}$ at $37^{\circ} \mathrm{C}$.

After dehydrating and clearing, all preparations were mounted with entellan (Merck, Darmstadt, Germany).

\section{Results}

A semi-quantitative evaluation of macrophages in vivo was chosen for two reasons. Firstly, it is impossible to isolate the different subpopulations of macrophages from the spleen for quantitation ex vivo. Because of their dendritic nature they remain associated with splenic debris. Secondly, macrophage subpopulations are not homogeneously distributed within the spleen. They are present in specific concentric compartments without a sharp border. ${ }^{22}$

\section{Repopulation of macrophages after exposure to $B$. abortus strain 544 antigen (group 2)}

The repopulation of spleen by macrophages after depletion with clodronate-containing liposomes in normal mice (group 2A) was studied and compared with the repopulation by macrophages in animals subsequently exposed to $\mathrm{BA}$ and various other antigens (group 2B). Injection of BA 544 (500 $\mu \mathrm{g} /$ mouse) after depletion resulted in accelerated repopulation of all macrophage subsets (table I).

In the mice that were not given BA 544, repopulation by RPM was completed within 2 weeks, but RPM reached their normal concentration in the red pulp within 2 days after administration of BA 544. The RPM were identified by their acid phosphatase (AP) activity and by their reaction with MAb F4-80. Detection of AP activity and F4-80-specific surface antigens showed a similar time-course. Repopulation of MMM was also accelerated after BA 544 exposure. Completion of repopulation was about twice as fast as in control mice without BA administration. Again, the presence of AP activity and MOMA-1 positivity were detected concurrently. The situation at day 8 is shown in fig. 1A and B in which spleen sections of mice have 
Table I. Macrophage subsets in depleted spleen and liver after exposure of mice to BA 544 antigen (group 2B)*

\begin{tabular}{|c|c|c|c|c|c|c|c|c|}
\hline \multirow{3}{*}{$\begin{array}{l}\text { Day } \\
\text { no. }\end{array}$} & \multicolumn{6}{|c|}{ Spleen } & \multicolumn{2}{|c|}{$\begin{array}{c}\text { Liver } \\
\text { (Kupffer cells) }\end{array}$} \\
\hline & \multicolumn{2}{|c|}{ RPM } & \multicolumn{2}{|c|}{ MMM } & \multicolumn{2}{|c|}{ MZM } & & \\
\hline & $\mathrm{AP}$ & $\mathrm{F} 4 / 80$ & $\mathrm{AP}$ & MOMA-1 & AP & ERTR-9 & AP & MOMA-1 \\
\hline 2 & $++(-)$ & $++(-)$ & $-(-)$ & $\pm(-)$ & $-(-)$ & $-(-)$ & $+(-)$ & $\pm(-)$ \\
\hline 4 & $\begin{array}{c}++( \pm) \\
5 \mathrm{Cl}\end{array}$ & $++(-)$ & $\pm(-)$ & $\pm(-)$ & $-(-)$ & $-(-)$ & $++\underset{1 \mathrm{Cl}}{ \pm}$ & $++(-)$ \\
\hline 8 & $\begin{array}{c}++(++) \\
7 \mathrm{Cl}^{* *}\end{array}$ & $++(+)$ & $+( \pm)$ & $+( \pm)$ & $-(-)$ & $-(-)$ & $\begin{array}{c}++(++) \\
20 \mathrm{Cl}\end{array}$ & $\begin{array}{r}++( \pm) \\
21 \mathrm{Cl}\end{array}$ \\
\hline 16 & $+\underset{5 \mathrm{Cl}^{* *}}{+(++)}$ & $++(++)$ & $++(+)$ & $++(+)$ & $-(-)$ & $-(-)$ & $\begin{array}{c}++(++) \\
8 \mathrm{Cl}\end{array}$ & $\begin{array}{c}++(++) \\
11 \mathrm{Cl}\end{array}$ \\
\hline 32 & $\begin{array}{c}++(++) \\
1 \mathrm{Cl}^{* *}\end{array}$ & $++(++)$ & $++(+)$ & $++(+)$ & $++( \pm)$ & $\pm(-)$ & $\begin{array}{c}++(++) \\
2 \mathrm{Cl}\end{array}$ & $++(++)$ \\
\hline 64 & $++(++)$ & $++(++)$ & $++(++)$ & $++(++)$ & $++(+)$ & $+(+)$ & $++(++)$ & $++(++)$ \\
\hline
\end{tabular}

*Results are from one study representative of three experiments. Mice were randomly divided into six groups of four mice. At least 10 sections, taken non-selectively from each organ, were assessed and results are presented as mean values of four mice. RPM, red pulp macrophages; MMM, marginal metallophilic macrophages; MZM, marginal zone macrophages. These macrophages can be detected by immunocytochemical staining with MAbs F4/80, MOMA-1 and ERTR-9 respectively, and by acid phosphatase (AP) staining: - , no cells stained positively; \pm , only very few cells positive;,$+ 10-50 \%$ of the normal number of cells;,$++>50 \%$ of the normal number of cells. Symbols in brackets represent the numbers of macrophage subsets in control mice (group $2 \mathrm{~A}$ ). $\mathrm{Cl}$, number of clusters of positive cells in samples from BA-treated mice; $\mathrm{Cl}^{* *}$, clusters of positive cells also present in white pulp. In the spleen the clusters were also NLDC-145positive and in the liver the clusters were also ERTR-9- and NLDC-145-positive.

been treated with MAb MOMA-1 to reveal the MMM. Repopulation by MZM was also accelerated. Thirtytwo days after exposure to BA 544 repopulation of the MZM subpopulation was evident whereas without BA, the MZM subpopulation was still incomplete after 64 days.

The acceleration of repopulation after injection of BA 544 was dose-dependent: no acceleration of repopulation of macrophages was observed after administration of $62.5 \mu \mathrm{g}$ or $125 \mu \mathrm{g}$ of BA $544 /$ mouse; after $250 \mu \mathrm{g}$ of BA 544, an accelerated repopulation was seen (results not shown), but it was less pronounced than after administration of $500 \mu \mathrm{g}$ of BA 544.

The repopulation kinetics of Kupffer cells (liver macrophages) with and without administration of BA 544 were similar to those described for RPM in the spleen. Repopulation of the liver by Kupffer cells was accelerated $c$. two-fold by exposure of mice to BA 544 antigen (table I).

In the bone marrow, an increase of AP-positive $\left(\mathrm{AP}^{+}\right)$cells was observed at day $0,48 \mathrm{~h}$ after intravenous injection of clodronate liposomes. Without further treatment, the number of $\mathrm{AP}^{+}$cells had returned to normal at day 8 . However, after the additional administration of BA 544, high levels of $\mathrm{AP}^{+}$cells were observed at day 2 . The increase was stronger and proved to be prolonged. After 8 days, $>85 \%$ of cells present were $\mathrm{AP}^{+}$compared with $49 \%$ in unstimulated bone marrow.

Another unexpected observation was the occurrence of clusters of cells in liver and spleen after administration of BA. These cell clusters were $\mathrm{AP}^{+}$and $\mathrm{NLDC}-145^{+}$. In the liver the clusters were also MOMA-1- and ERTR-9-positive (table I).

If, instead of BA $544, B$. melitensis $16 \mathrm{M}$ antigen $(500 \mu \mathrm{g} /$ mouse) was administered, similar results were obtained. B. ovis reo antigen ( $500 \mu \mathrm{g} / \mathrm{mouse})$ also induced an acceleration of repopulation of macrophages but to a lesser extent. The same dose of BA 19 antigen did not induce any marked acceleration of repopulation (results not shown).

No acceleration of the repopulation of macrophages in macrophage-depleted mice was seen after administration of LPS ( $E$. coli; 5 or $20 \mu \mathrm{g} / \mathrm{mouse}$ ), SRBC $\left(10^{8}\right.$ cells $)$, LPS-liposomes $(0 \cdot 2 \mathrm{ml}), E$. coli $(500 \mu \mathrm{g})$, L. acidophilus NCK89 $(500 \mu \mathrm{g})$, mannan $(0.2 \mathrm{ml}$ of mannan $1 \% \mathrm{w} / \mathrm{v}$ solution or $0.2 \mathrm{ml}$ of mannan $3 \% \mathrm{w} / \mathrm{v}$ solution) or TNF- $\alpha(1 \mathrm{ng})$.

\section{Antigen presentation by dendritic cells in the spleen}

To study the antigen presenting capacity of NLDC$145^{+}$cells in the spleen, 8 days after injection of BA 544 antigen in macrophage-depleted mice, a T-cell proliferation assay was performed. Dendritic cells were collected from macrophage-depleted and BA-treated mice (group 2B; DC*) and from control mice (group $1 \mathrm{~A}$; DC). There was a marked rise in the total number of cells in the spleens of BA-treated mice $\left(c .4 \times 10^{8}\right.$ cells c.f. c. $1 \cdot 8 \times 10^{8}$ cells in control spleens). Normally c. $4 \%$ of the DC were $\mathrm{NLDC}^{+}$, although in the case of treated mice (group 2B), $49 \%$ of the DC were $\mathrm{NLDC}^{+}$. The percentage of $\mathrm{MHC}$ Class $\mathrm{II}^{+}$cells was the same in both cases (results not shown). DC and DC* were tested for antigen presentation capability. Moreover, both types of DC were mixed to study the possibility of suppression of normal DC by DC* (fig. 2). In all cases, a non-specific response was present (black bars). This response was about three times higher with normal DC than with DC* alone or with the combination of $\mathrm{DC}$ and $\mathrm{DC}^{*}$ (ratio 1:1). The striped bars represent the OVA-specific response. In the case of $\mathrm{DC}^{*}$ alone, almost no specific response was observed. The re- 

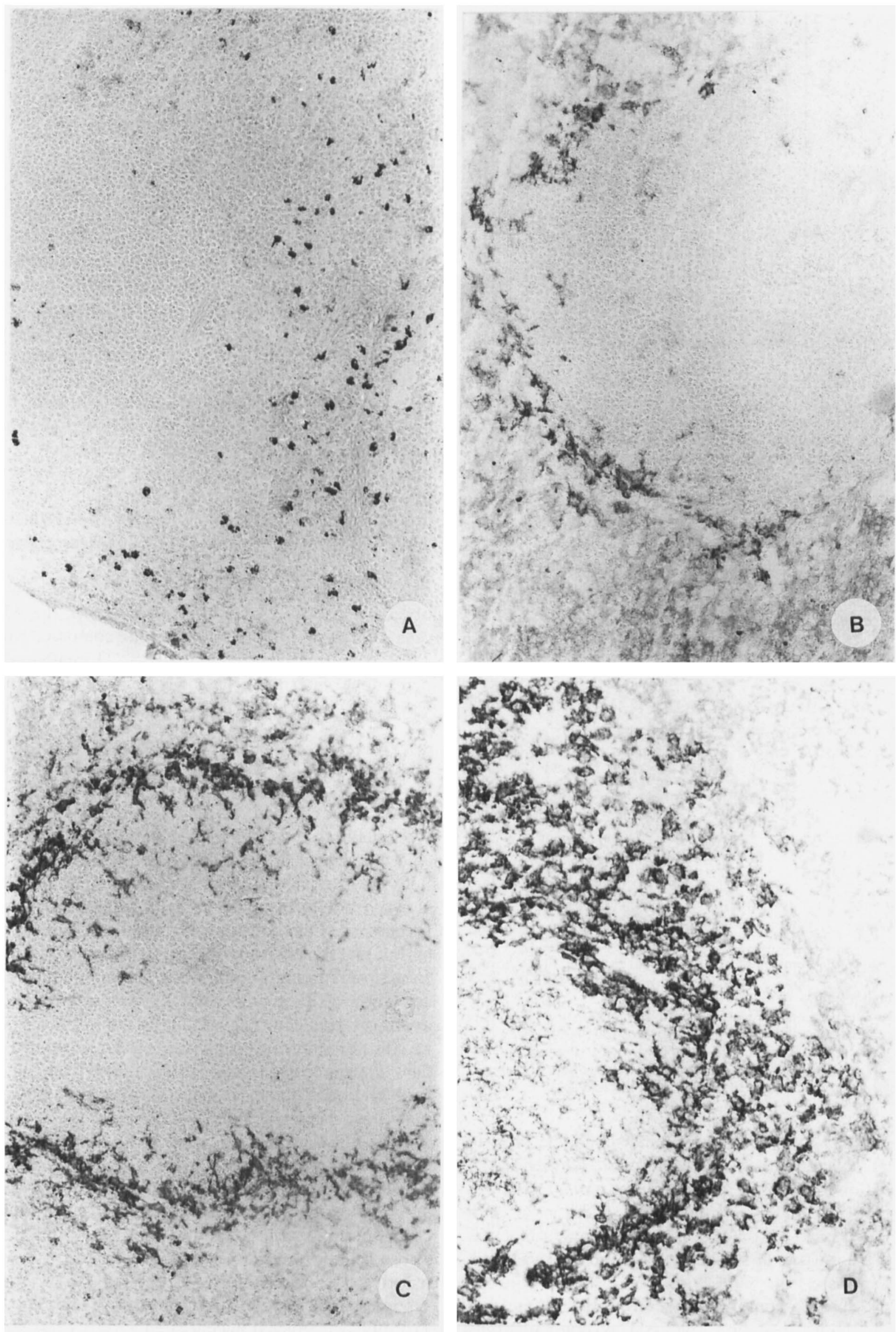

Fig. 1. Immunocytochemical staining of spleen sections with MAb MOMA-1 to detect MMM. MOMA-1 positive cells in macrophagedepleted spleen ( $\times 30)$ : A, control; B, 8 days after intravenous injection of $500 \mu \mathrm{g}$ of BA 544. MOMA-1-positive cells in normal spleen $(\times 30)$; C, control; D, 8 days after intravenous injection of $500 \mu \mathrm{g} \mathrm{BA} 544$. 


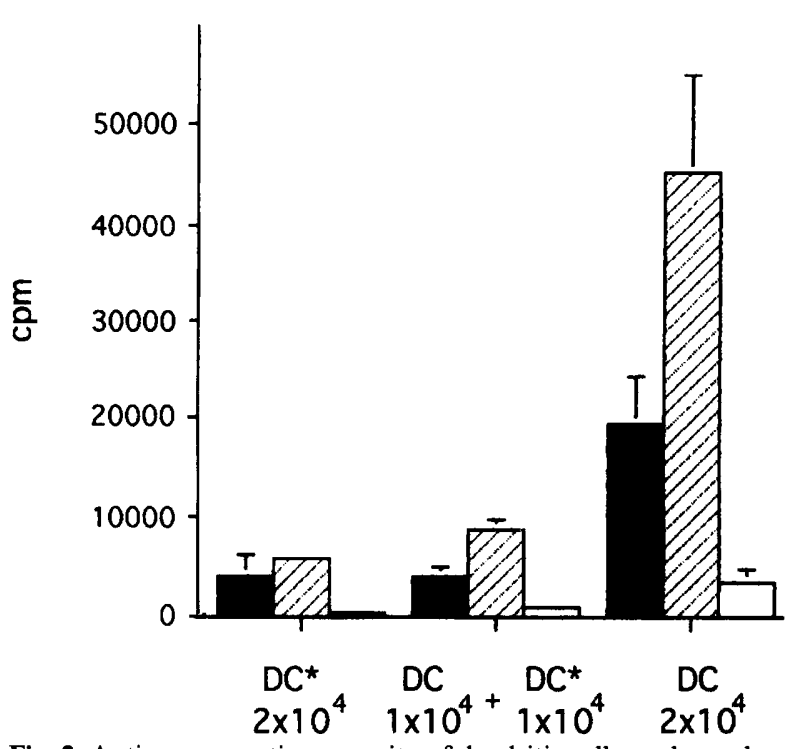

Fig. 2. Antigen-presenting capacity of dendritic cells as shown by a T-cell proliferation assay. Dendritic cells of group $2 \mathrm{~B}\left(\mathrm{DC}^{*}\right)$ and group 1A (DC) mice (day 8) were compared. DC and DC* were stimulated in vitro with ovalbumin ( $\square$ ) or were unstimulated ( $\square$ ). $\mathrm{T}$-cell proliferation in response to ovalbumin could be blocked by the addition of anti-MHC class II antibody M5/114 ( $\square$ ). Results are expressed as the mean cpm (bar, SD) of triplicate cultures.

Table II. Macrophage subsets in spleen and liver after exposure of normal mice to BA 544 antigen (group 1B)*

\begin{tabular}{|c|c|c|c|c|c|c|c|}
\hline \multirow{3}{*}{ Day } & \multicolumn{4}{|c|}{ Spleen } & \multirow{2}{*}{\multicolumn{3}{|c|}{$\begin{array}{c}\text { Liver } \\
\text { (Kupffer cells) }\end{array}$}} \\
\hline & \multirow{2}{*}{\multicolumn{2}{|c|}{$\frac{\mathrm{RPM}}{\mathrm{AP} F 4 / 80}$}} & \multirow{2}{*}{$\frac{\text { MMM }}{\text { MOMA-1 }}$} & \multirow{2}{*}{$\frac{\text { MZM }}{\text { ERTR-9 }}$} & & & \\
\hline & & & & & AP & MOMA-1 & $\mathrm{F} 4 / 80$ \\
\hline 2 & + & + & 0 & - & + & + & + \\
\hline 4 & + & + & + & - & $\underset{4 \mathrm{Cl}}{+}$ & + & + \\
\hline 8 & + & + & + & 0 & $\stackrel{+}{\mathrm{Cl}}$ & $20^{+} \mathrm{Cl}$ & $25_{\mathrm{Cl}}^{+}$ \\
\hline 16 & + & + & + & 0 & $\stackrel{+}{\mathrm{Cl}}$ & ${ }_{8 \mathrm{Cl}}^{+}$ & $\stackrel{+}{16 \mathrm{Cl}}$ \\
\hline 32 & + & + & + & 0 & $\begin{array}{c}0 \\
4 \mathrm{Cl}\end{array}$ & $\begin{array}{c}0 \\
4 \mathrm{Cl}\end{array}$ & $\begin{array}{c}0 \\
6 \mathrm{Cl}\end{array}$ \\
\hline 64 & + & + & 0 & 0 & $\begin{array}{c}0 \\
2 \mathrm{Cl}\end{array}$ & 0 & $\begin{array}{c}0 \\
1 \mathrm{Cl}\end{array}$ \\
\hline
\end{tabular}

,$-<$ normal numbers of cells; 0 , normal situation;,$+>$ normal numbers of cells; $\mathrm{Cl}$, clusters of positive cells in samples from BAtreated mice.

* Results from one study representative of three experiments. Mice were randomly divided into six groups of four mice. At least 10 sections, taken non-selectively from each organ, were assessed and results are presented as mean values of four mice. Subpopulations of macrophages are described in the legend of table I.

sponse (specific and non-specific) could be blocked totally by addition of anti-MHC class II antibodies. If $\mathrm{DC}$ alone were used, ${ }^{3} \mathrm{H}$-incorporation in $\mathrm{T}$ cells was high (45403 SD $9916 \mathrm{cpm})$. After addition of antiMHC class II antibodies, the response was blocked. When a mixture of DC and DC* (ratio $1: 1$ ) was used, a decrease of $80 \%$ in the ${ }^{3} \mathrm{H}$-incorporation (8951 SD $1037 \mathrm{cpm}$ ) was observed. If DC* alone were used, ${ }^{3} \mathrm{H}$-incorporation (5965 SD $245 \mathrm{cpm}$ ) was only $87 \%$ of that seen with DC alone. In both cases, the response was blocked after addition of anti-MHC class II antibodies.
The effect of $B A 544$ antigen on macrophages and dendritic cells in normal mice

In normal (non-depleted) mice, different effects on the macrophages were observed after injection of BA 544. In the spleen, changes in the different macrophage subpopulations were evident by day 2 (table II). An increase of the RPM population was seen and this was still evident at day 64. The number of MMM had increased at day 4 after BA 544 injection but had returned to normal at day 64 . The situation at day 8 is shown in fig. $1 C$ and $D$, in which spleen sections of mice have been treated with MAb MOMA-1 to reveal the MMM. The number of ERTR-9-positive cells (MZM) decreased immediately after BA 544 injection but, after 8 days, the number had returned to normal.

In the liver, an increase of the number of Kupffer cells was observed immediately after injection of BA 544. After 16 days, the number had returned to normal (table II). In contrast to the spleen, cell clusters were observed. These clusters could be detected by acid phosphatase staining from day 4 until day 64 or by immunocytochemical staining with MAbs MOMA-1 and F4-80 from day 16 until day 32 or 64, respectively (table II).

In the bone marrow, an increase of $\mathrm{AP}^{+}$cells was observed. At day 2 after BA 544 injection, the $\mathrm{AP}^{+}$ cells had increased to $84 \%$ of the total compared with $48 \%$ in unstimulated bone marrow. Thereafter, the percentage of positive cells slowly decreased to normal values (results not shown).

\section{Discussion}

Injection of $B$. abortus 544 antigen accelerated the repopulation of the different macrophage subsets in spleen and liver after depletion of these cells by the liposome-mediated macrophage "suicide" technique. ${ }^{1}$ It is generally believed that macrophages derive from precursors in the bone marrow, although half of the splenic macrophages have been postulated to originate from local proliferation in the spleen. ${ }^{23}$ Thus, acceleration of the repopulation kinetics after BA 544 administration could have been by two mechanisms, i.e., the bone marrow could have been activated by BA 544 , and precursor cells released faster, or local proliferation of the macrophage subsets in the spleen may have been increased. In previous work with normal mice, we have shown that the MMM subpopulation of splenic macrophages is able to proliferate locally, whereas RPM and MZM were not able to proliferate locally under steady-state conditions. Treatment with $0.2 \mathrm{ml}$ of clodronate liposomes did not change this observation (unpublished observations). In the present work, the repopulation kinetics of all the macrophage subsets in macrophage-depleted mice treated with BA 544 were accelerated. Thus, depending on the macrophage subpopulation, the acceleration of repopulation could be by one or two mechanisms. 
Apart from an acceleration of the repopulation kinetics of the macrophage subsets, administration of BA 544 to normal (non-macrophage-depleted) mice showed that various subsets reacted differently to the presence of BA 544. The numbers of RPM and MMM increased, whereas the numbers of MZM decreased. The mechanism by which these differences are caused has still to be unravelled. It might be related to differences in the origin of the macrophage subsets. However, we have found that different macrophage subsets in the spleen are not differentiation steps in one line, and all subsets have their origin in the bone marrow (unpublished observations). The mechanism might also be related to differences in the microenvironment of the various macrophage subsets in the spleen. ${ }^{22}$ Part of the mechanism might be explained by dose-dependent effects. Acceleration of the repopulation kinetics could be obtained by administration of a high dose $(500 \mu \mathrm{g} /$ mouse) of BA 544 antigen to macrophage-depleted mice. At lower doses $(\leqslant 250 \mu \mathrm{g} /$ mouse), only a slight acceleration in repopulation or no acceleration at all could be observed. In the case of normal (not depleted, group 1) mice, macrophages were present and phagocytosed a large part of the injected BA 544 antigen. Thus, the resulting blood concentration was lower than in macrophagedepleted mice. This concentration may have been too low to activate the precursor cells. A possible role of the cells present in the micro-environment must also be considered. Mediators produced by non-depleted macrophages could downregulate the proliferation and differentiation of precursor cells.

The effects of various other antigens and bacteria were also studied. However, in this model, only bacteria related to $B$. abortus 544 , except $B$. abortus strain 19, were able to accelerate the repopulation of spleen and liver by macrophages. The O-polysaccharides of the smooth LPS of Brucella strains contain a homopolymer of 4,6-dideoxy-4-formamido- $\alpha$-Dmannopyranose residues. These O-polysaccharides occur in both $\mathrm{A}$ and $\mathrm{M}$ antigens which are immunodominant in B. abortus 544 and B. melitensis $16 \mathrm{M}$, respectively. ${ }^{24-26}$ However, differences in repopulation kinetics of macrophage subsets after injection of these Brucella strains were not observed. B. ovis reo 198 , which caused a less marked acceleration of repopulation, does not contain either antigen. ${ }^{27}$ Another difference between B. ovis reo 198 and B. abortus 544 or $B$. melitensis $16 \mathrm{M}$ is the inability of the latter to reduce nitrate or nitrite. ${ }^{27}$ One of these differences, or their combination, may be related in some way to the

\section{References}

1. van Rooijen N. The liposome-mediated macrophage 'suicide' technique. J Immunol Methods 1989; 124: 1-6.

2. van Rooijen N, Sanders A. Liposome mediated depletion of macrophages: mechanism of action, preparation of liposomes and applications. J Immunol Methods 1994; 174: 83-93.

3. van Rooijen N, Kors N, Kraal G. Macrophage subset difference in repopulation kinetics. In the rough strain B. abortus 19, the amount of LPS is low. This type of Brucella can be used as a carrier (adjuvant) in vaccines, because its LPS is not as toxic as LPS from $E$. coli. ${ }^{10}$

The effects of administration of different particulate antigens on macrophage repopulation kinetics were also studied. Some of the particulate antigens-E. coli EB1 and LPS-liposomes-have LPS on their surface and two of them-SRBC and L. acidophilus NCK89-were thymus-dependent antigens. None of these particulate antigens was able to accelerate the macrophage repopulation. Administration of free $E$. coli LPS or TNF- $\alpha$, which is a product released by cells in contact with LPS, was not able to influence the repopulation kinetics. Thus, we conclude that LPS is probably not important in the acceleration of the repopulation process. Injection of mannan, which is an important part of the LPS of Brucella-related strains and some other bacteria, did not accelerate repopulation.

In earlier studies, various intravenously injected particulate antigens (as in the present study: BA 544, L. acidophilus NCK89 and LPS-liposomes) were found to follow the same distribution pattern in spleen and liver. ${ }^{18}$ Thus, their distribution seems not to be a crucial factor in the specific effects of BA.

An unexpected observation during the present studies was the occurrence of dendritic cell markers on cells clustered in murine spleens. The mice were treated with clodronate-liposomes and, 2 days later, with BA 544 antigen. More cells than normal were identified as dendritic cells. ${ }^{19}$ Although they had the morphological appearance and cell markers which are characteristic of dendritic cells, a functional assay showed that they had an impaired antigen presentation function when compared to normal dendritic cells. It even seemed that these cells were suppressing the normal dendritic cell functions. There seems to be some similarity between these $\mathrm{NLDC}^{+}$cells and the cells observed during chronic inflammation in the peritoneum of mice. ${ }^{28}$ Treatment with clodronate liposomes in itself did not affect the antigen presentation capability of dendritic cells (unpublished observations).

In conclusion, although BA stimulated the proliferation of precursors of all of the macrophage subsets in the spleen and liver, it also affected mature members of the mononoclear phagocyte system such as MZM and dendritic cells in spleen.

This work was supported by The Netherlands Organisation for Scientific Research (NWO) grant 900-505-224. The authors thank Gerdien Dijkstra for correcting the English text.

repopulation in the spleen: differential kinetics after liposome-mediated elimination. $J$ Leukocyte Biol $1989 ; 45$ : 97-104.

4. Golding B, Chang SP, Golding H et al. Human lymphocytes can generate thymus-independent as well as thymus dependent anti-hapten plaque-forming cell responses in vitro. J Immunol 1981; 127: 220-224.

5. Golding B, Muchmore AV, Blease RM. Newborn and WiskottAldrich patient B cells can be activated by TNP-Brucella 
abortus: evidence that TNP-Brucella behaves as a Tindependent type 1 antigen in humans. $J$ Immunol 1984; 133: 2966-2971.

6. Mond JJ, Scher I, Mosier DE, Baese M, Paul WE. Tindependent responses in $\mathrm{B}$ cell-defective $\mathrm{CBA} / \mathrm{N}$ mice to Brucella abortus and to trinitrophenyl (TNP) conjugates of Brucella abortus. Eur J Immunol 1978; 8: 459-463.

7. Brooks-Worrell BM, Splitter GA. Antigens of Brucella abortus S19 immunodominant for bovine lymphocytes as identified by one- and two-dimensional cellular immunoblotting. Infect Immun 1992; 60: 2459-2464.

8. Doyle AG, Halliday WJ, Barnett CJ, Dunn TL, Hume DA. Effect of recombinant human macrophage colonystimulating factor 1 on immunopathology of experimental brucellosis in mice. Infect Immun 1992; 60: 1465-1472.

9. Goud SN, Muthusamy N, Subbarao B. Differential responses of B cells from the spleen and lymph node to TNP-Ficoll. J Immunol 1988; 140: 2925-2930.

10. Goldstein J, Hoffman T, Frasch C et al. Lipopolysaccharide (LPS) from Brucella abortus is less toxic than that from Escherichia coli, suggesting the possible use of $B$. abortus or LPS from $B$. abortus as a carrier in vaccines. Infect Immun $1992 ; 60$ : 1385-1389.

11. Kraal G, Janse M. Marginal metallophilic cells of the mouse spleen identified by a monoclonal antibody. Immunology 1986; 58: 665-669.

12. Dijkstra CD, van Vliet E, Döpp EA, van der Lelij AA, Kraal G. Marginal zone macrophages identified by a monoclonal antibody: characterization of immuno- and enzymehistochemical properties and functional capacities. Immunology 1985; 55: 23-30.

13. van Vliet E, Melis M, van Ewijk W. Marginal zone macrophages in the mouse spleen identified by a monoclonal antibody. Anatomical correlation with a B cell subpopulation. $J$ Histochem Cytochem 1985; 33: 40-44.

14. Kraal G, Rep M, Janse M. Macrophages in T and B cell compartments and other tissue macrophages recognized by monoclonal antibody MOMA-2. An immunohistochemical study. Scand J Immunol 1987; 26: 653-661.

15. Austyn JA, Gordon S. F4/80, a monoclonal antibody directed specifically against the mouse macrophage. Eur J Immunol $1981 ; 11: 805-815$.

16. Kraal G, Breel M, Janse M, Bruin G. Langerhans' cells, veiled cells, and interdigitating cells in the mouse recognized by a monoclonal antibody. J Exp Med 1986; 163: 981-997.
17. Kraal G, Avis L, Wijfels JFAM, Hoeben $\mathrm{K}$, ter Hart $\mathrm{H}$. Different epitopes on the dendritic cell-associated NLDC145 molecule during ontogeny. Immunobiology 1990; 181 : 388-397.

18. Buiting AMJ, de Rover Z, Claassen E, van Rooijen N. In vivo distribution of particulate antigens and liposomes in murine spleen. A possible role in the humoral immune response. Immunobiology 1993; 188: 13-22.

19. Breel M, Mebius RE, Kraal G. Dendritic cells of the mouse recognized by two monoclonal antibodies. Eur J Immunol 1987; 17: 1555-1559.

20. Burstone MS. Histochemical comparison of naphtol ASphosphates for the demonstration of phosphatases. $J$ Natl Cancer Inst 1958; 20: 601-615.

21. Davis BJ, Ornstein L. High resolution enzyme localization with a new diazo reagent 'hexazonium pararosaniline'. $J$ Histochem Cytochem 1959; 7: 297-298.

22. van Rooijen N, Claassen E, Kraal G, Dijkstra CD. Cytological basis of immune functions of the spleen. Immunocytochemical characterization of lymphoid and nonlymphoid cells involved in the 'in situ' immune response. Progr Histochem Cytochem 1989; 19: 1-71.

23. van Furth R, Diesselhoff-den Dulk MMC. Dual origin of mouse spleen macrophages. J Exp Med 1984; 160: 1273-1283.

24. Bundle DR, Cherwonogrodzky JW, Gidney MAJ, Meilke PJ, Perry MB, Peters T. Definition of Brucella A and M epitopes by monoclonal typing reagents and synthetic oligosaccharides. Infect Immun 1989; 57: 2829-2836.

25. Garin-Bastuji B, Bowden RA, Dubray G, Limet JN. Sodium dodecyl sulfate-polyacrylamide gel electrophoresis and immunoblotting analysis of smooth-lipopolysaccharide heterogeneity among Brucella biovars related to $\mathrm{A}$ and $\mathrm{M}$ specificities. J Clin Microbiol 1990; 28: 2169-2174.

26. Meilke PJ, Perry MB, Cherwonogrodzky JW, Bundle DR. Fine structure of $\mathrm{A}$ and $\mathrm{M}$ antigens from Brucella biovars. Infect Immun 1989; 57: 2820-2828.

27. Corbel MJ, Brinley-Morgan WJ. Brucella. In: Krieg NR, Holt JG (eds) Bergey's Manual of systemic bacteriology, vol. 1. Baltimore/London, Williams and Wilkins Co. 1984: 377.

28. Wijffels JFAM, de Rover Z, van Rooijen N, Kraal G, Beelen RHJ. Chronic inflammation induces the expression of dendritic cell markers not related to functional antigen presentation on peritoneal exudate macrophages. Immunobiology 1991; 184: 83-92. 